\title{
Correction to: Using different levels of energy and protein and their effects on bodyweight and blood chemistry of ostriches
}

\author{
Tahereh Nikravesh-Masouleh $^{1} \cdot$ Alireza Seidavi $^{1} \cdot$ Magdalena Solka $^{2} \oplus \cdot$ Mohammad Dadashbeiki $^{3}$
}

Published online: 16 June 2021

C) Springer Nature B.V. 2021

\section{Correction to: Veterinary Research Communications https://doi.org/10.1007/s11259-021-09792-5}

The correct affiliations 1 and 3 are as below:

1 Department of Animal Science, Rasht Branch, Islamic Azad University, Rasht, Iran

3 Department of Veterinary Medicine, Rasht Branch, Islamic Azad University, Rasht, Iran

The original article has been corrected.

Publisher's note Springer Nature remains neutral with regard to jurisdictional claims in published maps and institutional affiliations.

The original article can be found online at https://doi.org/10.1007/ s11259-021-09792-5

Alireza Seidavi

alirezaseidavi@iaurasht.ac.ir

$\triangle$ Magdalena Solka

m.solka@igbzpan.pl

1 Department of Animal Science, Rasht Branch, Islamic Azad University, Rasht, Iran

2 Department of Genomics and Biodiversity, Institute of Genetics and Animal Biotechnology of the Polish Academy of Sciences, 05-552 Jastrzębiec, Magdalenka, Poland

3 Department of Veterinary Medicine, Rasht Branch, Islamic Azad University, Rasht, Iran 